\title{
Genetic Variability, Yield and Yield Associations of Lentil (Lens culinaris Medic.) Genotypes Grown at Gitilo Najo, Western Ethiopia
}

\author{
Alemayheu Dugassa $^{1^{\star}}$, Hirpa Legesse ${ }^{2}$ and Negash Geleta ${ }^{2}$
}

\author{
${ }^{1}$ Leka Nekemte Preparatory School, Nekemte Ethiopia \\ ${ }^{2}$ College of Agriculture and Natural Resources, Wollega University, Post Box No: 395, Nekemte, Ethiopia
}

\begin{tabular}{|c|c|}
\hline Abstract & Article Information \\
\hline $\begin{array}{l}\text { The study was conducted to evaluate the variability in yield, heritability, genetic advance and } \\
\text { associations among characters, to estimate contribution of each trait in yield of the eighteen } \\
\text { lentil genotypes. The genotypes were grown at Wollega University, Shambu Campus, Gitilo } \\
\text { Najo Research Site. The genotypes were planted in RCBD and replicated three times. Data } \\
\text { were collected for } 12 \text { morpho-agronomic traits. The results of the analysis of variance showed } \\
\text { significant ( } P<0.05 \text { ) difference for all traits among the genotypes except for number of } \\
\text { primary branches and hundred seed weight. The heritability values for the } 12 \text { characters } \\
\text { ranged from } 4.3 \% \text { (hundred seed weight) to } 94.3 \% \text { (days to emergency). Estimates } \\
\text { heritability values for days to emergence, plant height, number of pods per plant, biomass } \\
\text { yield are }>60 \% \text { while for days to flowering, days to maturity, grain filling period and harvest } \\
\text { index are between } 40 \% \text { and } 60 \% \text {. Estimates of genetic advance as percent of mean at } 5 \% \\
\text { selection intensity ranged from } 0.59 \% \text { (hundred seed weight) to } 78.1 \% \text { (number of pods per } \\
\text { plant). High heritability values coupled with high genetic advance as percent mean were } \\
\text { observed for number of pods per plant and biomass yield which indicates the traits are } \\
\text { controlled by additive type of genes. A low genotypic coefficient of variability and low genetic } \\
\text { advance as a percent mean observed for characters hundred seed weight and pod length } \\
\text { indicated that the characters were under high environmental influence, and that phenotypic } \\
\text { selection based on these characters would be ineffective. Days to } 50 \% \text { flowering showed } \\
\text { positive and highly significant correlation with days to } 95 \% \text { maturity at genotypic and } \\
\text { phenotypic levels. Both at genotypic and phenotypic levels, grain yield was positively and } \\
\text { significantly correlated with plant height and biomass yield while it was negatively and } \\
\text { significantly correlated with harvest index. The result revealed wide variability for yield and } \\
\text { yield determining traits for the tested genotypes which will help in the improvement of lentil } \\
\text { genotypes for the area. } \\
\text { Copyright@2014 STAR Journal. All Rights Reserved. }\end{array}$ & $\begin{array}{l}\text { Genotype } \\
\text { Lentil } \\
\text { Yield } \\
\text { Yield associations } \\
\text { Variability } \\
\text { “Corresponding Author: } \\
\text { Alemayehu Dugassa } \\
\text { E-mail: } \\
\text { alexdugasa@gmail.com }\end{array}$ \\
\hline
\end{tabular}

\section{INTRODUCTION}

Lentil (Lens culinaris Medik) belongs to the genus Lens of the Viceae tribe in the Legumnosae (Fabaceae) family, commonly known as the legume family. It is a free standing legume divided into two sub-species; the cultivated variety (Lens culinaris) and its wild relative (Lens orientalis) (Edossa et al., 2010). The cultivated lentil (Lens culinaris), ssp. culinaris, has two varietal types: small seeded (microsperma) and large seeded (macrosperma). Lentil is a short, slender, self pollinated annual diploid $(2 n=2 x=14)$ which exhibits a wide range of morphological variations (Sarker and Erskine, 2001).

Ethiopia ranks first in Africa and tenth in the world in lentil production (Sarker et al., 2003; Geletu and Yadeta, 1999). Currently lentil covers an area of about 90,000 hectares with an annual production of 125,008 tones; the average national productivity being about 1.17 tones/ha (CSA, 2013). It is an important part of the farming system in Ethiopia. Farmers and their families use it to make nifro, sambusa shorba and wot, a soup, which supplements their diet with lysine, an amino acid essential for the human body. The diets in Ethiopia, where barley and tef are the staple food, are often deficient in lysine (Geletu et al., 1996).

Lentil is a major source of protein (28\%) for human consumption and its straw is a valued animal feed consisted of minerals (2\%) and carbohydrates (59\%) (Frederick et al., 2006). Lentil seed is indigestible, constipating tonic and useful in diseases of chest and for ulcer treatment (Gupta, 1992). In Ethiopia, lentils are mostly cultivated for domestic consumption. However the demand and request for both grain and split red cotyledon is very high in India, Lebanon and Srilanka. Because of significant economic role and social conditions lentil production has recently been expanding in both stressed and non-stressed environments (Asnake and Geletu, 2003). 
Alemayheu Dugassa et alo,

The other reason lentils have played a vital role in Ethiopian traditional farming systems is their ability to take nitrogen directly from the atmosphere and fix it in a form plants can use in the major lentil producing highlands of Ethiopia, where black clay soils dominate, planting of lentil is done usually late in rainy season. This exposes the crop to terminal moisture stress during flowering and podding stages and result in low economic yield due to either flower abortion and /or impeded synthesis and assimilates translocation to filling grain. If very late maturing lines are planted in the late season, they will not even flower due to desiccating dry winds against their slow development. This is why most of the Ethiopian lentils are of early to medium maturing types (Asnake and Geletu, 2003)

Genetic variation between and within populations of crop species is a major interest of plant breeders and geneticists (Edossa et al., 2007). The breeders must have the idea of choosing the accession that most likely possesses the trait of interest. Targeted and more efficient utilization of germplasm by plant breeders can be achieved if the trait characteristics of accessions are known (Abebe, 2008; Fratini et al., 2007).

The positive association of pairs of characters shows the possibility of correlated response to selection and it indicates that with the increase in one character, there is going to be an increment in the other. In contrary to this, the negative correlation precludes the simultaneous improvement of those traits along with each other.

Main concern with lentil is low yield potential because of narrow genetic base of the local cultivars. The key to increase lentil yield in Ethiopia is through widening the
Sci. Technol. Arts Res. J., Oct-Dec 2014, 3(4): 10-18

available genetic base. This narrow genetic variability among indigenous germplasm has restricted breeding progress in Ethiopia. Knowledge on the extent and pattern of genetic variability present in a population is absolutely essential for further improvement of the crop. Similarly, information on the extent and nature of interrelationship among character help in formulating efficient scheme of multiple trait selection. Such information is scanty especially in Lentil genotypes grown in Western part of Ethiopia. Therefore, this research was designed to evaluate the heritability, genetic advance and associations among characters of lentil genotypes and to estimate contribution of each trait to yield improvement in lentil genotypes

\section{MATERIALS AND METHODS}

\section{Description of Study Site}

The experiment was conducted at Gitilo Najo of Wollega university research site located in Horo District of Horo Guduru Wollega Zone of Oromia Regional State about $8 \mathrm{~km}$ from Shambu town and $348 \mathrm{~km}$ from Addis Ababa. The area is characterized by highland agroecology (2850 masl) with mixed farming (crop and livestock production) as a main livelihood of the rural community. The area is also suitable for lentil production with clay-loam type of soil, annual rainfall of 1800 $2000 \mathrm{~mm}$ and the highest and lowest temperature of the area is $21^{\circ} \mathrm{C}$ and $10^{\circ} \mathrm{C}$, respectively.

\section{Experimental Materials}

In the study eighteen lentil genotypes were obtained from the Institute of Biodiversity Conservation (IBC). The lentil genotypes are listed in Table 1.

Table 1: List of Lentil Genotypes used for the study

\begin{tabular}{cccccc}
\hline No. & $\begin{array}{c}\text { Genotypes/ } \\
\text { Accessions }\end{array}$ & $\begin{array}{c}\text { Collected } \\
\text { from }\end{array}$ & $\begin{array}{c}\text { Original } \\
\text { Seed source }\end{array}$ & $\begin{array}{c}\text { Altitude } \\
\mathbf{( m )}\end{array}$ & $\begin{array}{c}\text { Type of } \\
\text { genotype }\end{array}$ \\
\hline 1 & ILL36004 & IBC & Amhara/Shewa & 3180 & Local varieties \\
2 & ILL215249 & IBC & Amhara/Wello & 3170 & Local varieties \\
3 & ILL235012 & IBC & Amhara/Wello & 2950 & Local varieties \\
4 & ILL235013 & IBC & Amhara/Wello & 3450 & Local varieties \\
5 & ILL235014 & IBC & Amhara/Wello & 3340 & Local varieties \\
6 & ILL235015 & IBC & Amhara/Wello & 3110 & Local varieties \\
7 & ILL235016 & IBC & Amhara/Shewa & 3040 & Local varieties \\
8 & ILL235017 & IBC & Amhara/Shewa & 3040 & Local varieties \\
9 & ILL237502 & IBC & Amhara/Shewa & 2950 & Local varieties \\
10 & ILL238977 & IBC & Amhara/Gondar & 2880 & Local varieties \\
11 & ILL238991 & IBC & Oromiya/ Shewa & 2840 & Local varieties \\
12 & ILL241782 & IBC & Amhara/Gondar & 3055 & Local varieties \\
13 & ILL241783 & IBC & Amhara/Gondar & 2890 & Local varieties \\
14 & ILL243433 & IBC & Amhara/Wello & 3335 & Local varieties \\
15 & ILL243434 & IBC & Amhara/Wello & 2920 & Local varieties \\
16 & ILL243436 & IBC & Amhara/Wello & 3450 & Local varieties \\
17 & ILL243437 & IBC & Amhara/Wello & 3145 & Local varieties \\
18 & ILL243438 & IBC & Amhara/Wello & 3025 & Local varieties \\
\hline \multicolumn{7}{c}{ IBC= Institute of biodiversity conservation } &
\end{tabular}

\section{Treatments and Experimental Design}

Genotypes/accessions were assigned as a treatment. The experimental design used was RCBD with 3 replications. The genotypes were planted on $1.5 \mathrm{~m} \times 1 \mathrm{~m}$ $\left(1.5 \mathrm{~m}^{2}\right)$ plot area. The spacing was $30 \mathrm{~cm}$ between rows and $8 \mathrm{~cm}$ between plants. There were three rows per plot and 54 experimental units. Firm, weed-free seed beds on well-drained soils were prepared for and the seeds were 
Alemayheu Dugassa et alo,

planted. All other crop management and protection practices were undertaken following previous research recommendations.

\section{Data Collection and Analysis}

\section{Phenological Data}

1. Days to emergence: The number of days taken from planting to emergence of the seedlings.

2. Days to $50 \%$ flowering: It was recorded as number of days from planting to a stage where $50 \%$ of the plants in a plot produce flower.

3. Days to $95 \%$ physiological maturity: It was recorded as the number of days from planting to a stage when $95 \%$ of the plants in a plot produce matured pods.

4. Grain filling period: The period in days from $50 \%$ flowering to $95 \%$ maturity.

\section{Growth Parameters}

1. Plant height: The height in centimeters from the ground level to the tip of the plant for 5 randomly selected plants at physiological maturity.

2. Number of primary branches per plant: The average number of primary branches for five plants randomly taken from the plot.

3. Number of secondary branches per plant: The average number of secondary branches on each plant was recorded from five randomly selected plants per plot.

\section{Yield Components}

1. Number of pods per plant: It is the average number pods per plant for five randomly selected plants per plot at harvest.

2. Number of seeds per pod: The average number of seeds per pod which was recorded from ten randomly taken pods from each plot.

3. Pod length $(\mathrm{cm})$ : The average length of pod for five randomly taken pods from each plot measured using ruler.

4. 100 Seed weight $(\mathrm{g})$ : hundred seed weight was recorded from 100 seeds taken from each plot by counting 100 seeds.

5. Biomass yield $(\mathrm{kg} / \mathrm{ha})$ : It was recorded by weighing the total above ground biomass harvested from each experimental plot at the time of harvest.

6. Seed yield $(\mathrm{kg} / \mathrm{ha})$ : It was obtained by weighing the seeds from each experimental plot at standard moisture level.

7. Harvest index: The ratio of dry seed weight to the above ground biomass yield.

\section{Data Analysis}

Data was subjected to analysis of variance using the GLM procedure of SAS software (SAS, 2004). Genotypes were considered as fixed effects whereas replications were taken as random effects in the statistical model. Treatment means that exhibited significant differences were separated using the student-Neuman Keuls test (SNK) at $5 \%$ level of significance (SAS, 2004). Multivariate analysis such as PCA and cluster analysis were performed by using SAS software.

\section{Estimation of Genetic Parameters}

The genotypic and phenotypic coefficients of variability were undertaken according to the formulae of Singh and Chaundary (1991)

Genotypic Coefficient of Variation GCV $=\frac{\sigma g}{X} 100 \%$
Sci. Technol. Arts Res. J., Oct-Dec 2014, 3(4): 10-18

Phenotypic Coefficient of Variation PCV $=\frac{\sigma \mathrm{p}}{X} 100 \%$

Where, $\sigma \mathrm{g}$ and $\sigma \mathrm{p}$ are genotypic and phenotypic standard deviations, respectively.

\section{Broad-sense Heritability and Genetic Advance}

From breeding point of view usefulness of heritability is related to its onward transmission from the parent to the progeny (Raiz and Chowdhury, 2003). Broad sense heritability $\left(h^{2}\right)$ expressed as the percentage of the ratio of the genotypic variance $\left(\sigma^{2} \mathrm{~g}\right)$ to the phenotypic variance $\left(\sigma^{2} p\right)$ and was estimated on genotype mean basis as: Heritability in broad sense calculated as:

$$
\mathrm{h} 2 \mathrm{~b}=\frac{\sigma 2 \mathrm{~g}}{\sigma 2 \mathrm{p}} \times 100 \%
$$

The genotypic and phenotypic variances were estimated as:

$$
\begin{gathered}
\sigma 2 g=\frac{M S g-\text { MSe }}{r} \\
\sigma^{2} p=\sigma^{2} g+\sigma^{2} e
\end{gathered}
$$

Where, $\sigma^{2} g=$ genotypic variance, $\sigma^{2} p=$ phenotypic variance, $\mathrm{MSg}=$ Mean square due to genotypes /accessions, MSe = Mean square of error, and $r=$ number of replications. Genetic advance in absolute unit (GA) and percent of the mean (GAM), assuming selection of superior $5 \%$ of the genotypes was estimated as:

$$
\mathrm{GA}=\mathrm{K} \sigma \mathrm{p} \mathrm{h}^{2}
$$

$$
\mathrm{GAM}=\frac{\mathrm{GA}}{\mathrm{X}} \times 100 \%
$$

Where, $\mathrm{k}=$ the standardized selection differential at $5 \%$ selection intensity and $(\mathrm{K}=2.063), \sigma \mathrm{P}=$ phenotypic standard deviation, $\mathrm{h}^{2}=$ heritability and $x=$ Grand mean

\section{Analysis of Phenotypic and Genotypic Correlation Coefficients}

To estimate phenotypic and genotypic correlation coefficients between all pairs of characters was computed following the same as variance analysis.

$$
\text { Genotypic correlation coefficient, } \mathrm{rg}=\frac{\operatorname{covg}(\mathrm{xy})}{\sigma \mathrm{g}(\mathrm{x}) * \sigma \mathrm{g}(\mathrm{y})}
$$$$
\text { Phenotypic correlation coefficient, } \mathrm{rph}=\frac{\operatorname{cov} \mathrm{ph}(\mathrm{xy})}{\sigma \mathrm{ph}(\mathrm{x}) * \sigma \mathrm{ph}(\mathrm{y})}
$$

Where, COVg (xy) and COVph (xy) are the genotypic and phenotypic covariance of two variables ( $X$ and $Y$ ), respectively. $\sigma \mathrm{g}(\mathrm{x})$ and $\sigma \mathrm{g}(\mathrm{y})$ are the genotypic standard deviations for variables, $\mathrm{X}$ and $\mathrm{Y}$, respectively. $\sigma \mathrm{ph}(\mathrm{x})$ and $\sigma p h(y)$ are the phenotypic standard deviations of variables, $\mathrm{X}$ and $\mathrm{Y}$, respectively.

The calculated phenotypic correlation value was tested for its significance using t-test:

$$
\mathrm{t}=\mathrm{rph} / \mathrm{SE}(\mathrm{rph})
$$

Where: $r p h=$ Phenotypic correlation; SE $(r p h)=$ Standard error of phenotypic correlation obtained using the following formula (Sarker et al., 2003).

\section{Character Associations}

The positive association of pairs of characters shows the possibility of correlated response to selection and it indicates that with the increase in one character. In 
Alemayheu Dugassa et alo,

contrary to this, the negative correlation precludes the simultaneous improvement of those traits along with each other (Gemechu et al., 2005).

\section{RESULTS AND DISCUSSION}

Results obtained on variability assessment, associations among yield and yield related characters and genetic divergence are presented here under. Implications of such studies in lentil improvement and breeding program for higher seed yield and other traits of interest are also discussed.
Sci. Technol. Arts Res. J., Oct-Dec 2014, 3(4): 10-18

\section{Analysis of Variance}

The analysis of variance for the 12 characters studied is given in Table 2. There was a highly significant difference $(P<0.001)$ among the tested genotypes for days to emergence, days to flowering, days to $95 \%$ maturity, grain filling period, plant height, number pods per plant and harvest index. Significant difference $(P<0.05)$ was observed for pod length, biological yield and grain yield. Non-significant difference was observed for traits like number of primary branches per plant and hundred seed weight (Table 2).

Table 2: ANOVA table showing mean squares for genotypes, error mean square and replication mean squares

\begin{tabular}{lccc}
\hline \multicolumn{1}{c}{ Parameters } & $\begin{array}{c}\text { Replication } \\
\text { (Df=2) }\end{array}$ & $\begin{array}{c}\text { Genotypes } \\
\text { (Df=17) }\end{array}$ & $\begin{array}{c}\text { Error } \\
\text { (Df=34) }\end{array}$ \\
\hline Days to emergence & 0.02 & $0.99^{\star *}$ & 0.02 \\
Days to 50\% flowering & 12.06 & $34.2^{* *}$ & 6.51 \\
Days to 95\% maturity & 5.79 & $17.99^{* *}$ & 4.17 \\
Days to grain filling period & 7.91 & $14.09^{* *}$ & 4.67 \\
Plant height, cm & 3.75 & $29.74^{* *}$ & 1.94 \\
Number of primary branches & 1.13 & $0.62 \mathrm{~ns}$ & 0.35 \\
Number of pods per plant & 1.09 & $428.6^{* *}$ & 17.2 \\
Pod length, cm & 0.058 & $0.024^{*}$ & 0.012 \\
Hundred seed weight, g & 0.076 & $0.057 \mathrm{~ns}$ & 0.05 \\
Biological yield (t/ha) & 0.128 & $0.339^{*}$ & 0.028 \\
Grain yield (t/ha) & 0.015 & $0.019^{*}$ & 0.001 \\
Harvest index & 0.001 & $0.002^{* *}$ & 0.001 \\
\hline
\end{tabular}

Where, $\mathrm{Df}=$ Degrees of freedom, ns=non-significant,

* and ** indicates significant and highly significant respectively

On average all the genotypes were emerged eight days after planting. Accession number ILL235017 was late in emergence as compared to the rest accessions (Table 3). High variability was observed among genotypes tested for days to flowering, maturity and grain filling period. On average genotypes were took 85,120 and 37 days to flower, mature and grain filling period, respectively. All genotypes were matured on average of 120 and half days after planted, and the grain filling periods for the genotypes were 37 days after flowering. Genotypes like ILL36004, ILL235013, ILL235015, ILL238977, ILL241782 and ILL243438 emerge earlier than the other genotypes. Genotype ILL235017 is the last emerged one among the sown genotypes. ILL243438 is the earliest genotype to give flower among the other genotypes and ILL235017 is the one that gave flower last. Genotype ILL243438 matured earlier than the other genotypes and ILL36004 matured late as compared to the rest genotypes tested. When we compare their grain filling period ILL235014, ILL235016, ILL235012, ILL241782, ILL238977, ILL243433 and ILL215249 were earlier than the other genotypes where as ILL235013, ILL235015, ILL238991 and ILL36004 had delayed grain filling period, and ILL243438 was the last genotypes in grain filling period. Low coefficient of variation were recorded for days to emergency (1.8), days to $50 \%$ flowering (3.0), days to maturity (1.7), grain filling period (6.1). Very wide ranges were recorded for days to $50 \%$ flowering (75.7-89), days to $90 \%$ maturity (117-127) and grain filling period (3341.3) in this study.

High significant differences were observed among lentil genotypes tested for plant height, but non-significant differences were observed among genotypes for number of primary branches per plant (Table 4). On average the genotypes gave $30.6 \mathrm{~cm}$ with the range of $26-38.3 \mathrm{~cm}$ (Table 4). The coefficient of variation for all of the tested entries were recorded as for; plant height (4.56), number of primary branches per plant (22.2). Relatively taller plants were recorded from genotypes ILL235016, and followed by ILL36004 and ILL241782 (Table 4). On the other hand shorter plants were recorded from ILL235014, ILL238991 and ILL235013.

Table 3: Mean performance of four traits recorded as affected by genotypes

\begin{tabular}{|c|c|c|c|c|}
\hline Genotypes & $\begin{array}{c}\text { Days to } \\
\text { Emergency }\end{array}$ & $\begin{array}{l}\text { Days to } \\
\text { flowering }\end{array}$ & $\begin{array}{l}\text { Days to } \\
\text { maturity }\end{array}$ & $\begin{array}{l}\text { Grain } \\
\text { filling } \\
\text { period }\end{array}$ \\
\hline ILL36004 & $7.0^{c}$ & $87.6^{\mathrm{ba}}$ & $127.0^{\mathrm{a}}$ & $39.3^{\mathrm{ba}}$ \\
\hline ILL215249 & $8.0^{\mathrm{b}}$ & $87.3^{\mathrm{ba}}$ & $122.0^{\mathrm{bc}}$ & $34.6^{b}$ \\
\hline ILL235012 & $8.0^{\mathrm{b}}$ & $84.0^{\mathrm{abc}}$ & $118.0^{\mathrm{bc}}$ & $34.0^{b}$ \\
\hline ILL235013 & $7.0^{\mathrm{c}}$ & $82.3^{\mathrm{bac}}$ & $118.6^{b c}$ & $36.3^{\text {ba }}$ \\
\hline ILL235014 & $8.0^{\mathrm{b}}$ & $87.3^{\mathrm{ba}}$ & $120.3^{b c}$ & $33.0^{b}$ \\
\hline ILL235015 & $7.0^{c}$ & $80.6^{\mathrm{bdc}}$ & $118^{\mathrm{bc}}$ & $37.3^{\text {ba }}$ \\
\hline ILL235016 & $8.0^{b}$ & $86.3^{\text {bac }}$ & $119.6^{\mathrm{bc}}$ & $33.3^{b}$ \\
\hline ILL235017 & $9.0^{\mathrm{a}}$ & $89.0^{a}$ & $124.0^{\mathrm{ba}}$ & $35.0^{b}$ \\
\hline ILL237502 & $8.0^{b}$ & $84.6^{\mathrm{bac}}$ & $120.0^{\mathrm{bc}}$ & $35.3^{b}$ \\
\hline ILL238977 & $7.0^{\mathrm{c}}$ & $86.0^{\text {bac }}$ & $120.3^{b c}$ & $34.3^{b}$ \\
\hline ILL238991 & $8.0^{b}$ & $79.6^{d c}$ & $118.0^{\mathrm{bc}}$ & $38.3^{\text {ba }}$ \\
\hline ILL241782 & $7.0^{\mathrm{c}}$ & $86.7^{\text {bac }}$ & $120.6^{b c}$ & $34.0^{b}$ \\
\hline ILL241783 & $8.0^{\mathrm{b}}$ & $83.0^{\text {bac }}$ & $118.3^{b c}$ & $35.3^{b}$ \\
\hline ILL243433 & $8.0^{b}$ & $86.0^{\mathrm{bac}}$ & $120.3^{b c}$ & $34.3^{b}$ \\
\hline ILL243434 & $7.3^{c}$ & $86.0^{\text {bac }}$ & $121.3^{\mathrm{bc}}$ & $35.3^{b}$ \\
\hline ILL243436 & $8.0^{\mathrm{b}}$ & $87.0^{\text {bac }}$ & $122.0^{\mathrm{bc}}$ & $35.0^{b}$ \\
\hline ILL243437 & $8.0^{b}$ & $86.6^{\mathrm{bac}}$ & $122.0^{\mathrm{bc}}$ & $35.3^{b}$ \\
\hline ILL243438 & $7.0^{\mathrm{c}}$ & $75.6^{d}$ & $117.0^{c}$ & $41.3^{\mathrm{a}}$ \\
\hline Mean & 7.7 & 84.78 & 120.4 & 35.6 \\
\hline CV (\%) & 1.8 & 3.010 & 1.790 & 6.06 \\
\hline
\end{tabular}

N.B: Mean with the same letter are not significantly different 
Table 4: Mean performance of eight traits recorded as affected by genotypes. Mean with the same letter are not significantly different.

\begin{tabular}{|c|c|c|c|c|c|c|c|c|}
\hline Genotypes & $\mathrm{PH}(\mathrm{cm})$ & NPB & NPP & PL cm) & HSW(g) & BY (t/ha) & GY (t/ha) & $\mathrm{HI}$ \\
\hline ILL36004 & $34.3^{\mathrm{bc}}$ & $2.3^{\mathrm{ns}}$ & $62.5^{\mathrm{a}}$ & $1.6^{\mathrm{ab}}$ & $3.37^{\text {ns }}$ & $2.5^{\mathrm{a}}$ & $0.96^{\mathrm{a}}$ & $0.27^{\text {cab }}$ \\
\hline ILL215249 & $28.3^{\text {gehf }}$ & $2.0^{\mathrm{ns}}$ & $24.5^{\mathrm{e}}$ & $1.8^{\mathrm{ab}}$ & $3.6^{\mathrm{ns}}$ & 1. $9^{\text {cde }}$ & $0.80^{\mathrm{ab}}$ & $0.29^{\mathrm{cab}}$ \\
\hline ILL235012 & $30.6^{\text {decf }}$ & $3.3^{\text {ns }}$ & $23.7^{\text {ef }}$ & $1.9^{\mathrm{a}}$ & $3.1^{\mathrm{ns}}$ & $1.7^{\mathrm{de}}$ & $0.77^{\mathrm{ab}}$ & $0.31^{\mathrm{ab}}$ \\
\hline ILL235013 & $27.0^{\text {gh }}$ & $3.0^{\mathrm{ns}}$ & $23.3^{\mathrm{ef}}$ & $1.8^{\mathrm{ab}}$ & $3.3^{\text {ns }}$ & $2.1^{\mathrm{cdb}}$ & $0.75^{\mathrm{ab}}$ & $0.26^{\mathrm{cab}}$ \\
\hline ILL235014 & $26.0^{\mathrm{h}}$ & $2.6^{\mathrm{ns}}$ & $21.3^{\mathrm{ef}}$ & $1.8^{\mathrm{ab}}$ & $3.3^{\mathrm{ns}}$ & $1.6^{\mathrm{e}}$ & $0.71^{\mathrm{ab}}$ & $0.30^{\mathrm{cab}}$ \\
\hline ILL235015 & $30.0^{\text {dgef }}$ & $3.0^{\mathrm{ns}}$ & $41.7^{\mathrm{b}}$ & $1.7^{\mathrm{ab}}$ & $3.4^{\mathrm{ns}}$ & $1.8^{\text {cde }}$ & $0.83^{\mathrm{ab}}$ & $0.30^{\mathrm{cab}}$ \\
\hline ILL235016 & $38.3^{a}$ & $2.0^{\mathrm{ns}}$ & $13.3^{9}$ & $1.9^{\mathrm{ab}}$ & $3.5^{\mathrm{ns}}$ & $2.5^{\mathrm{ab}}$ & $0.84^{\mathrm{ab}}$ & $0.25^{\mathrm{cb}}$ \\
\hline ILL235017 & $31.3^{\mathrm{dbec}}$ & $2.6^{\mathrm{ns}}$ & $31.3^{\mathrm{cd}}$ & $1.8^{\mathrm{ab}}$ & $3.2^{\mathrm{ns}}$ & $1.6^{\mathrm{e}}$ & $0.66^{b}$ & $0.28^{\mathrm{cab}}$ \\
\hline ILL237502 & $29.0^{\text {dgehf }}$ & $3.0^{\mathrm{ns}}$ & $17.2^{\mathrm{fg}}$ & $1.8^{\mathrm{ab}}$ & $3.3^{\text {ns }}$ & $1.8^{\mathrm{de}}$ & $0.85^{\mathrm{ab}}$ & $0.33^{\mathrm{a}}$ \\
\hline ILL238977 & $26.6^{g h}$ & $2.0^{\mathrm{ns}}$ & $19.8^{\text {efg }}$ & $1.8^{\mathrm{ab}}$ & $3.2^{\mathrm{ns}}$ & $1.6^{\mathrm{e}}$ & $0.67^{b}$ & $0.29^{\mathrm{cab}}$ \\
\hline ILL238991 & $27.3^{\mathrm{ght}}$ & $2.33^{\mathrm{ns}}$ & $19.7^{\text {efg }}$ & $1.7^{\mathrm{ab}}$ & $3.3^{\mathrm{ns}}$ & $1.6^{\mathrm{e}}$ & $0.66^{b}$ & $0.29^{\mathrm{cab}}$ \\
\hline ILL241782 & $34.6^{b}$ & $2.0^{\mathrm{ns}}$ & $21.7^{\text {ef }}$ & $1.6^{\mathrm{b}}$ & $3.4^{\mathrm{ns}}$ & $1.9^{\text {cde }}$ & $0.82^{\mathrm{ab}}$ & $0.29^{\mathrm{cab}}$ \\
\hline ILL241783 & $31.3^{\mathrm{dbec}}$ & $2.33^{\text {ns }}$ & $32.7^{\mathrm{cd}}$ & $1.8^{\mathrm{ab}}$ & $3.8^{\mathrm{ns}}$ & $1.7^{\mathrm{de}}$ & $0.82^{\mathrm{ab}}$ & $0.31^{\mathrm{ab}}$ \\
\hline ILL243433 & $32.6^{\mathrm{dbc}}$ & $3.0^{\mathrm{ns}}$ & $34.0^{c}$ & $1.8^{\mathrm{ab}}$ & $3.4^{\mathrm{ns}}$ & $1.9^{\text {cde }}$ & $0.81^{\mathrm{ab}}$ & $0.29^{\mathrm{cab}}$ \\
\hline ILL243434 & $28.8^{\text {dgehf }}$ & $2.67^{\mathrm{ns}}$ & $46.7^{\mathrm{b}}$ & $1.8^{\mathrm{ab}}$ & $3.4^{\mathrm{ns}}$ & $2.4^{\mathrm{ab}}$ & $0.76^{\mathrm{ab}}$ & $0.24^{c}$ \\
\hline ILL243436 & $31.0^{\mathrm{dbect}}$ & $2.67^{\text {ns }}$ & $33.7^{c}$ & $1.8^{\mathrm{ab}}$ & $3.1^{\mathrm{ns}}$ & $2.5^{\mathrm{ab}}$ & $0.82^{\mathrm{ab}}$ & $0.25^{\mathrm{cb}}$ \\
\hline ILL243437 & $31.6^{\mathrm{dbec}}$ & $3.0^{\mathrm{ns}}$ & $26.2^{\text {de }}$ & $1.7^{\mathrm{ab}}$ & $3.2^{\mathrm{ns}}$ & $2.3^{\mathrm{cab}}$ & $0.86^{\mathrm{ab}}$ & $0.27^{\mathrm{cab}}$ \\
\hline ILL243438 & $31.0^{\text {dbect }}$ & $3.33^{\text {ns }}$ & $32.0^{\mathrm{cd}}$ & $1.9^{\mathrm{ab}}$ & $3.3^{\mathrm{ns}}$ & $2.1^{\mathrm{cdb}}$ & $0.81^{a b}$ & $0.28^{\mathrm{cab}}$ \\
\hline Mean & 30.6 & 2.63 & 29.2 & 1.80 & 3.30 & 1.99 & 0.79 & 0.28 \\
\hline CV (\%) & 4.56 & 22.3 & 14.2 & 6.03 & 6.80 & 8.33 & 11.1 & 8.01 \\
\hline
\end{tabular}

Where $n s=n$ non significant, $P H=$ plant height,$N P B=$ Number of primary branches per plant, $N P P=$ Number of pods per plant, $P L=P o d$ Length, HSW= Hundred Seed weight, BYtha = Biomass Yield, GYtha= Grain Yield and HI= Harvest Index in percentage.

High significant differences were observed among lentil genotypes for most yield related traits, grain and biomass yield and Harvest index (Table 4). On average the genotypes gave $1.8 \mathrm{~cm}, 3.3 \mathrm{gm}, 1.99 \mathrm{t} / \mathrm{ha}, 0.79 \mathrm{t} / \mathrm{ha}$ and 0.28 for pod length, hundred seed weight, biomass yield, grain yield and harvest index, respectively(Table 4). The coefficient of variation for all of the tested entries were recorded as number of pods per plant $12.3 \%$, pod length $6.03 \%$, hundred seed weight $6.8 \%$, biomass yield $8.33 \%$, grain yield $11.1 \%$ and harvest index $8.01 \%$. As reported by Mondal et al.,(2007), significant differences are found among lentil accessions for days to first flowering, days to maturity, plant height, number of branches, number of pods per plant, number of seeds per pod, 100-seed weight and seed yield per plant except plant height and number of branches per plant. Medium coefficient of variation was recorded for number of pods per plant (12.30), grain yield per hectare (11.07), biomass yield (8.33) and harvest index (8.01). Top yielding 5 lentil accessions (genotypes) are identified as; ILL36004, ILL243437, ILL237502, ILL235016 and ILL235015. Very wide ranges (69-182.5) were recorded for number pod per plant. Narrow ranges were recorded for days to emergency (7-9), number of primary branches per plant (2-3.33), pod length (1.58-1.93), hundred seed weight (3.07-3.6), biomass yield (1.6-2.57) and grain yield (0.66$0.97)$ in ton per hectare and harvest index (0.24-0.33).

\section{Phenotypic and Genotypic Coefficient of Variations}

The amount of genotypic and phenotypic variability that exists in a species is essential in developing better varieties and in initiating a breeding program. Genotypic and phenotypic coefficients of variation are used to measure the variability that exists in a given population (Gemechu et al., 2005). Estimated variance components, phenotypic coefficient of variability (PCV) and genotypic coefficient of variability (GCV) of the characters studied are presented in Table 5.

The phenotypic coefficient of variation (PCV) was generally much higher than genotypic coefficient of variation (GCV) for all characters considered indicating that environment is important in determining these traits. Relatively very high GCV was observed for number of pods per plants (40.1), days to $95 \%$ maturity (17.89), and biomass yield per plot (16.21). High GCV was recorded for number of primary branches per plant (11.54), plant height (9.97), grain yield (9.81), days to emergency (7.5) and harvest index (6.90). In line with this result, Malik et al., (1994) found that sufficient genetic variability in lentil germplasm in traits like plant height, number of pods per plant and grain yield per plant. Tigist (2003) had also reported that high GCV for number of branches, plant height and days to emergency. Seifu, (1998) had reported that high GCV for number of primary branches per plant and plant height.

Higher PCV was observed for number of pods per plant (42.6), number of primary branches per plant (25.51) and days to $95 \%$ maturity (24.72). High PCV was recorded for biomass yield per hectare (18.12), plant height (10.94), harvest index (10.9) and grain yield per hectare (10.59). The estimated PCV was relatively low for days to emergency, days to flowering, grain filling period, pod length and hundred seed weight. This finding agrees with the result reported by Edossa et al. (2010) in Ethiopian lentil landraces for number of pods, plant height, and days to flowering. However, the differences between PCV and GCV values for days to $95 \%$ maturity, number of primary branches per plant, pod length, hundred seed weight and harvest index were wide. High GCV recorded in biomass and grain yield per plant, number of primary branches, and plant height indicates that the variation exist will allow selection to improve these characters. These results are in agreement with those recorded by Afiah and Moselhy (2001). Days to emergency, days to flowering, grain filling period, pod length and hundred seed weight showed lower estimates of PCV indicating little opportunity for selection to improve these traits. In line with this result Singh and Singh, (1997) and Sinha and Choudhury (1991) were reported lower estimates of variability for these traits. 
Table 5: Genotypic and phenotypic coefficient of variability, heritability, genetic advance, and genetic advance percent of the mean of the 12 traits of Lentil varieties

\begin{tabular}{llllllllll}
\hline Traits & Mean \pm SE & Range & $\boldsymbol{\sigma}^{2} \mathbf{g}$ & $\boldsymbol{\sigma}^{2} \mathbf{p}$ & $\mathbf{G C V}(\%)$ & $\mathbf{P C V}(\%)$ & $\mathbf{h}^{2}(\%)$ & GA & GAM (\%) \\
\hline DE & $7.69 \pm 0.00$ & $7.0-9.0$ & 0.33 & 0.35 & 7.5 & 7.69 & 94.3 & 1.15 & 14.96 \\
DF & $84.8 \pm 2.10$ & $75.7-89.0$ & 9.24 & 15.8 & 3.58 & 4.69 & 58.7 & 4.81 & 5.67 \\
DM & $12 \pm 1.67$ & $117-127$ & 4.61 & 8.8 & 17.89 & 24.72 & 52.5 & 3.21 & 26.74 \\
GFP & $35.6 \pm 1.70$ & $33.0-41.3$ & 3.14 & 7.8 & 4.98 & 7.85 & 40.2 & 2.31 & 6.50 \\
PH & $30.6 \pm 1.10$ & $26.0-38.3$ & 9.30 & 11.2 & 9.97 & 10.94 & 82.7 & 5.70 & 18.63 \\
NPB & $2.6 \pm 0.50$ & $2.0-3.3$ & 0.09 & 0.44 & 11.54 & 25.51 & 21.1 & 0.29 & 11.09 \\
NPP & $29.2 \pm 4.2$ & $13-62.5$ & 137.1 & 154.3 & 40.1 & 42.6 & 88.9 & 22.8 & 78.1 \\
PL & $1.79 \pm 0.09$ & $1.58-1.90$ & 0.004 & 0.02 & 3.53 & 7.90 & 26.4 & 0.08 & 4.30 \\
HSW & $3.33 \pm 0.18$ & $3.07-3.60$ & 0.002 & 0.05 & 1.34 & 6.71 & 4.3 & 0.02 & 0.59 \\
BY & $1.99 \pm 0.14$ & $1.6-2.6$ & 0.104 & 0.13 & 16.21 & 18.12 & 78.9 & 0.59 & 29.49 \\
GY & $0.79 \pm 0.07$ & $0.7-0.9$ & 0.006 & 0.007 & 9.81 & 10.59 & 33.2 & 0.06 & 7.24 \\
HI & $0.29 \pm 0.02$ & $0.24-0.3$ & 0.0004 & 0.001 & 6.90 & 10.90 & 43.73 & 0.03 & 9.82 \\
\hline
\end{tabular}

$\mathrm{SE}=$ Standard Error, $\sigma^{2} \mathrm{~g}=$ genotypic variance, $\sigma^{2} \mathrm{p}=$ phenotypic variance, $\mathrm{GCV}(\%)=$ Genotypic coefficient of variation, $\mathrm{PCV}(\%)=$ phenotypic coefficient of variation, $\mathrm{h}^{2}(\%)=$ heritability in broad sense, $\mathrm{GA}=$ Genetic advance, $\mathrm{GAM}=$ Genetic mean advance, $\mathrm{DE}=$ days to Emergency, $\mathrm{DF}=$ Days to $50 \%$ Flowering, $\mathrm{DM}=$ days to maturity, GFP=Grain filling period, $\mathrm{PH}=$ plant height $(\mathrm{cm}), \mathrm{NPB}=\mathrm{Number}$ of primary branches per plant, NPP $=$ Number of pods per plant, $\mathrm{PL}=$ Pod Length, HSW= Hundred Seed weight, BYtha= Biomass Yield in ton per hectare, GYtha= Grain Yield in ton per hectare and $\mathrm{HI}=$ Harvest Index in percentage.

\section{Heritability Estimates in Broad Sense}

The estimated heritability for the 12 studied characters is presented in table 5 . The heritability values for the 12 characters ranged from $4.26 \%$ to $94.3 \%$. As reported by Wright, (1991), heritability values are helpful in Predicting the expected progress to be achieved through the process of selection on genetic coefficient of variation along with heritability estimate provides a reliable estimate of the amount of genetic advance to be expected through phenotypic selection. High heritability value for number of pods per plant (88.9) coupled with high PCV (42.6) and GCV (40.1), and plant height (82.68\%) with high PCV $(10.94 \%)$ and GCV (9.97\%) was observed indicating selection for this trait may respond effectively for phenotypic selection of lentil grown in high land area.

Singh and Ceccerelli (1996) stated that if heritability of a character is very high, say $80 \%$ or more, selection for such character should be fairly easy. This is because there would be a close correspondence between the genotypes and phenotypes due to the relatively small contribution of the environment effect to the phenotypes. But, for characters with low heritability, say $40 \%$ or less, selection may be considerably difficult or virtually impractical due to the masking effect of the environment. The result obtained in this study indicated that, heritability estimate was recorded as moderate $(40-80 \%)$ for traits like biomass yield $(78.96 \%)$, days to $50 \%$ flowering $(58.68 \%)$, days to maturity $(52.5 \%)$, harvest index $(43.7 \%)$, and grain filling period $(40.21 \%)$. Moderate estimate of heritability for harvest index have been reported by Yadav et al., (2003). However, Fratini et al., (2007) and Abebe (2008), stated that harvest index was a highly heritable trait in the lentil accessions and therefore could be targeted as a trait for selection in a breeding program with parents from that accession.

Low estimates of heritability values were recorded for traits like number of primary branches per plant $(21.2 \%)$, pod length $(26.4 \%)$, hundred seed weight $(4.3 \%)$ and grain yield $(33.2 \%)$. Likewise low estimates of heritability value with lowest values of GCV was observed for traits hundred seed weight indicating that phenotypic selection for these traits is difficult. In this study, lowest estimate of heritability was observed for hundred seed weight (4.3\%); thereby indicating limited possibility of improvement for this trait through selection.

\section{Estimates of Expected Genetic Advance}

The genetic advance as the percentage of the mean (GAM) at $5 \%$ selection intensity is presented in table 5 below. Estimates of genetic advance as percent of mean at $5 \%$ selection intensity ranged from 0.59 for hundred seed weight to 78.1 for number of pod per plant.

The highest genetic advance was observed for number of pod per plant (Table 5). There was relatively high genetic advance expressed as percentage of mean for biomass yield/plot (29.49) with high value of heritability, PCV and GCV values. The highest and lowest genetic advance as percent mean were recorded for number of pod per plant (78.1) and hundred seed weight (0.59) respectively. The low expected genetic advances were recorded for traits like number of primary branches per plant, pod length, hundred seed weight, grain/biomass yield per hectare and harvest index, which are due to low variability for these traits indicated by respective low GCV's and PCV's(Table 5).

Therefore, even if heritability estimates provide basis for selection on the phenotypic performance, the estimates of heritability and genetic advance should always be considered simultaneously, high heritability is not always associated with high genetic advance as reported by Yadav et al., (2003). Likewise, estimates of genetic advance (as percent of the mean) for days to emergency, days to $95 \%$ maturity, plant height, primary branches per plant, number of pods per plant and biomass yield per hectare were also considerably high (Table 5). A low GCV and low GAM were observed for characters like hundred seed weight and pod length indicated that the characters were under high environmental influence, and that selection based on these characters would be ineffective.

\section{Estimates of Correlation Coefficients}

Seed yield is the result of many characters which are interdependent. Breeders always look for genetic variation among traits to select desirable types. Some of these characters are highly associated among themselves and with seed yield. 
Alemayheu Dugassa et alo,

As reported by Singh and Ceccerelli (1996), the analysis of the relationship among these characters and their association with seed yield is essential to establish selection criteria. Estimates of correlation coefficients between each pair of characters were presented in Table 6 and 7 . Similar results were also obtained on lentil crop
Sci. Technol. Arts Res. J., Oct-Dec 2014, 3(4): 10-18

by Sharma (1999). Improvement for a target character can be achieved by indirect selection via other characters that are more heritable and easy to select. This selection strategy requires understanding the interrelationship of the characters among themselves and with the target character.

Table 6: Phenotypic correlation coefficients (rp) of yield and yield related traits for the 18 Lentil genotypes grown at Gitilo Najo Research site of Wollega University (in 2013/14 growing season)

\begin{tabular}{|c|c|c|c|c|c|c|c|c|c|c|c|c|}
\hline Variable & DE & DF & DM & GFP & PH & NPB & NPP & PL & HSW & BYtha & GYtha & $\mathrm{HI}$ \\
\hline$\overline{D E}$ & 1.00 & $0.31^{*}$ & 0.10 & $-0.33^{*}$ & 0.03 & 0.03 & $-0.28^{*}$ & 0.15 & -0.08 & -0.27 & -0.23 & 0.12 \\
\hline DF & & 1.00 & $0.71^{* \star *}$ & $-0.67^{* * *}$ & 0.2 & -0.22 & 0.13 & -0.2 & 0.11 & 0.11 & 0.09 & -0.03 \\
\hline DM & & & 1.00 & 0.05 & 0.22 & -0.22 & $0.29^{*}$ & -0.2 & -0.07 & $0.29^{*}$ & 0.26 & -0.1 \\
\hline GFP & & & & 1.00 & -0.06 & 0.08 & 0.13 & 0.01 & -0.22 & 0.16 & 0.15 & -0.06 \\
\hline $\mathrm{PH}$ & & & & & 1.00 & -0.06 & 0.03 & -0.2 & 0.16 & $0.43^{* *}$ & $0.35^{* *}$ & -0.18 \\
\hline NPB & & & & & & 1.00 & 0.16 & 0.08 & -0.23 & 0.02 & -0.16 & -0.18 \\
\hline NPP & & & & & & & 1.00 & -0.1 & -0.17 & $0.35^{* *}$ & 0.17 & -0.25 \\
\hline PL & & & & & & & & 1.00 & -0.01 & -0.05 & -0.003 & 0.11 \\
\hline HSW & & & & & & & & & 1.00 & 0.06 & 0.19 & 0.12 \\
\hline BYtha & & & & & & & & & & 1.00 & $0.54^{* * *}$ & $-0.6^{* * *}$ \\
\hline GYtha & & & & & & & & & & & 1.00 & $0.30^{*}$ \\
\hline $\mathrm{HI}$ & & & & & & & & & & & & 1.00 \\
\hline
\end{tabular}

Where $\mathrm{DE}=$ days to Emergency, $\mathrm{DF}=$ Days to $50 \%$ Flowering, $\mathrm{DM}=$ days to maturity, GFP=Grain filling period, $\mathrm{PH}=\mathrm{plant}$ height $(\mathrm{cm}$ ), $\mathrm{NPB}=$ Number of primary branches per plant, NPP = Number of pods per plant, $\mathrm{PL}=$ Pod Length, HSW= Hundred Seed weight, $\mathrm{BY}$ tha= Biomass Yield in ton per hectare, GYtha= Grain Yield in ton per hectare and $\mathrm{HI}=$ Harvest Index in percentage.

Table 7: Genotypic correlation coefficients $(\mathrm{rg})$ of yield and yield related traits for the 18 Lentil genotypes grown at Gitilo Najo Research site of Wollega University (in 2013/14 growing season)

\begin{tabular}{lllllllllllll}
\hline Variable & DE & DF & DM & GFP & PH & NPB & NPP & PL & HSW & BYtha & GYtha & HI \\
\hline DE & 1.0 & 0.39 & 0.16 & -0.43 & 0.05 & 0.03 & -0.32 & 0.25 & -0.15 & -0.28 & -0.29 & 0.51 \\
DF & & 1.00 & $0.8^{* * *}$ & $-0.7^{* *}$ & 0.21 & -0.43 & 0.19 & -0.2 & 0.01 & 0.15 & 0.07 & -0.12 \\
DM & & & 1.00 & -0.07 & 0.25 & -0.33 & 0.42 & -0.42 & -0.04 & 0.39 & 0.30 & -0.29 \\
GFP & & & & 1.00 & -0.04 & 0.29 & 0.18 & -0.15 & -0.06 & 0.22 & 0.23 & -0.14 \\
PH & & & & & 1.00 & -0.19 & 0.04 & -0.16 & 0.29 & $0.52^{*}$ & $0.62^{* *}$ & -0.19 \\
NPB & & & & & & 1.00 & 0.32 & 0.25 & $-0.5^{*}$ & -0.01 & 0.07 & 0.11 \\
NPP & & & & & & & 1.00 & -0.09 & -0.23 & 0.46 & 0.43 & -0.25 \\
PL & & & & & & & & 1.00 & 0.02 & -0.17 & -0.19 & 0.14 \\
HSW & & & & & & & & & 1.00 & 0.09 & 0.33 & 0.11 \\
BYtha & & & & & & & & & & 1.00 & $0.66^{* *}$ & $-0.8^{* *}$ \\
GYtha & & & & & & & & & & & 1.00 & -0.04 \\
HI & & & & & & & & & & & & 1.00 \\
\hline
\end{tabular}

$\mathrm{DE}=$ days to Emergency, $\mathrm{DF}=$ Days to $50 \%$ Flowering, $\mathrm{DM}=$ days to maturity, GFP=Grain filling period, $\mathrm{PH}=$ plant height $(\mathrm{cm}), \mathrm{NPB}=$ Number of primary branches per plant, NPP $=$ Number of pods per plant, $\mathrm{PL}=$ Pod Length, HSW= Hundred Seed weight, BYtha= Biomass Yield in ton per hectare, GYtha $=$ Grain Yield in ton per hectare and $\mathrm{HI}=$ Harvest Index in percentage.

Positive and significant correlation of number of pods per plant with biological yield and seed yield was observed. In line with this result, Tigist (2003) reported that seed yield was positively correlated with plant height, number of pods per plant and biomass yield. Plant height had showed significant and positive correlation with biomass yield, and highly significant and positive correlation with grain yield (Table 7).

Positive correlation of plant height with seed yield has also been reported by Kumar et al., (2004), which was also reported by Tigist (2003) and Vir et al. (2001). Biological yield had highly significant and positive genotypic and phenotypic correlation with grain yield, and very highly significant and negative correlation with harvest index. Positive and very high significant correlation of days to $50 \%$ flowering and days to maturity has been observed.
Days to $50 \%$ flowering showed very highly significant and negative correlation with grain filling period. Harvest index showed very highly significant and negative correlation with biomass yield (Table 7). Fewer studies have associated biomass with other traits (Kumar et al., 2004).

Plant biomass was positively correlated with plant height, harvest index and grain yield per plant. Grain yield was significantly correlated with biomass yield and has positive relationship. In line with this result Kumar et al. (2004) had reported that grain yield had positive correlation with biological yield, 100-seed weight and harvest index. There was no significant relationship between grain yield and days to emergency, days to flowering, days to maturity, grain filling period, number of branches per plant, number of pods per plant, pod length, hundred seed weight and harvest index (Table 7). 
Moreover, grain yield was strongly correlated with both plant height and biomass at harvest, which was also reported by Kumar et al. (2004). Grain yield per plant, biomass yield per plant and plant height were significantly correlated with yield. Harvest index was very highly significant and negatively related to biomass yield.

\section{CONCLUSIONS}

Genetic variability of germplasm resources is necessary to sustain long-term genetic improvement of cultivars. The knowledge of genetic variation and relationships between populations is important to understand the available genetic variability and its potential use in breeding programs lentil crops. The present study generally implied the presence of significant genetic variability among the tested genotypes. Thus, there is an excellent opportunity to bring about improvement through direct selection and hybridization which involves crossing of genotypes from different clusters.

Understanding of the magnitude of variability present in crop plants and the degree of association between the different agronomic characters is of utmost importance as it provides the base for effective selection. Higher estimates of heritability and genetic advance were observed for days to emergency and plant height indicating that these characters are mainly controlled by additive genes and selection of such traits might be effective for the improvement of seed yield.

Generally, many of the tested genotypes of lentil were significantly different and most of them were expected to be contributes an important breeding value. It needs sustainable conservation and continues breeding activities. The results of this study indicate that there is considerable genetic variation among landraces evaluated for different traits and so that there is high genetic potential for yield improvement through selection. In conclusion, the present investigation indicated that there is wide range of genetic variability for the 12 characters studied. However, it would be advantageous to study more number of genotypes over the location and years to confirm the importance of these traits as direct contributor for grain yield.

Finally, the results and conclusions made on the genetic diversity of the lentil accessions for agronomic characters is based on data obtained from one year at a single site for field conditions. Therefore more number of accessions in more than one location for several years should be screened for further conclusion in the future for the improvement of the crop. For this matter, participation of governmental institutions and farmers associations is crucial.

\section{REFERENCES}

Abebe Tullu, I., Kusmenoglu, K. Phee and Muehlbauer, F. (2001). Characterization of Core Collection of lentil germplasms for penology, morphology, seed and straw yields. Genetic Recourse of Crop Evolution 48:143-152.

Abebe Tulu. (2008). Identification of quantitative trait loci (QTL) for plant structure, growth habit and yield in lentil. Spanish Journal of Agricultural Research 5(3): 348-356.

Afiah, S.A.N. and Moselhy. N.M.M. (2001). Evaluation of selected lentil genotypes under rainfed conditions of Ras
El-Hekma, North Western Coast. Annals of Agricultural Science-Ain-Shams University Cairo 46(2): 619-629.

Asnake Fikre and Geletu Bejiga (2003). Breeding lentil for wider adaptation. Genetic Resources and Crop Evolution 49: 557-564.

CSA (Central Statistics Agency). (2013). Central Statistics Agency Report on Area and Production of Crops. Stat. Bull. Agric. Sample Survey, Volume I, Addis Ababa, Ethiopia. PP.406

Edossa. F., Kassahun. T. and Endashaw. B. (2007). Genetic diversity and population structure of Ethiopian lentil (Lens culinaris Medikus) landraces as revealed by ISSR marker. African Journal of Biotechnology 6(12): 1460-1468.

Edossa. F., Kassahun. T and Endashaw. B. (2010). A comparative study of morphological and molecular diversity in Ethiopian lentil landraces. African Journal of Plant Science 4(7): 241-254.

Fratini, R., Durán, Y., García, P., Pérez, D. and Vega, M. (2007). Identification of quantitative trait loci (QTL) for plant structure, growth habit and yield in lentil. Spanish Journal of Agriculture Research 5(3): 348-356

Frederick. M., Cho, S., Sarker, A., McPhee, K., Coyne, C., Rajesh, P., and Ford, P. (2006). Application of biotechnology in breeding lentil for resistance to biotic and abiotic stress. Euphytica 147:149-165

Geletu Bejiga., Million Eshete and Yadeta Anbessa.(1996). Improved cultivars and production technology of lentil in Ethiopia. Research Bulletin No. 3. Debre Zeit Agricultural Research Center, Alemaya University, Debre Zeit, Ethiopia.

Geletu Bejiga and Yadeta Anbessa, (1999). Development of Rust-Resistant Lentil cultivars in Ethiopia. Lens Newsletter 26(1\&2), ICARDA, Aleppo, Syria.

Gemechu, K., Mussa, J., Tezera, W. and Getinet, D. (2005). Extent and pattern of genetic diversity for morphoagronomic traits in Ethiopian highland pulse landraces. 1. Field pea (Pisum sativum L.). Genetic Resource Crop Evolution 52: 801-808

Gupta, Y.P. (1992). Nutritive value of food legumes. In chemistry and biochemistry of legumes edited by S.K. Arora, Oxford and IBH publishing Co., New Delhi, pp. 287-327.

Kumar, A., Singh D.P. and Singh B.B. (2004). Association analysis in lentil. Indian Journal of Pulses Research (8)1: 20-24.

Malik, B., Tahir, M., Haqani, A. and Anwar, R. (1994). Documentation, characterization and preliminary evaluation of lentil (Lens culinaris) germplasm in Pakistan. Lens Newsletter 11(20): 8-11

Mondal, M., Howlader M., Akter M. and Dutta R. (2007). Evaluation of five advanced lentil mutants in relation to morph-physiological characters and yield. Bangladesh Journal of Crop Science 18(2): 367-372.

Raiz, R., and Chowdhry A. (2003). Estimation of variation and heritability of some physio70 morphic traits of wheat under drought condition. Asian Journal of Plant Science 2(10): 748-755

Sarker, A. and Erskine, W. (2001). Utilization of genetic Resources in lentil improvement. p. $42 \mathrm{ln}$ : Proceedings of the Genetic Resources of Field Crops: Genetic Resources Symposium, EUCARPIA, and Poznam, Poland 


\section{Alemayheu Dugassa et al.,}

Sarker, A., Erskine, W. and Singh, M. (2003). Variation in shoot and root characteristics and their association with drought tolerance in lentil landraces. Genetic Resourses Crop Evolution 52:87-95.

SAS, (2004). Statistical Analysis System, Version 9.01. Cary, North Carolina, USA.

Seifu Tsegaye. (1998). Correlation and path coefficient analysis in lentil (Lens culinaris Medik.) and their implication for selection. Msc Thesis. Alemaya Agricultural University, Ethiopia.

Sharma, S.K. (1999). Studies on genetic variability and correlation of grain yield and other quantitative characters in lentil (Lens culinaris Medik). Annals of Agricultural Bioresearch 4(1): 121-124.

Singh, D.P. and Singh, B.B. (1997). Evaluation of exotic germplasm in lentil. Journal of Agricultural Research 6(2): 304-306.
Sci. Technol. Arts Res. J., Oct-Dec 2014, 3(4): 10-18

Singh, M.P. and Ceccerelli R.B. (1996). Estimation of heritability of crop traits from variety trial data. Technical manual No. 20, ICARDA, Aleppo, Syria.

Sinha, R. and Chowdhury, S. (1991) Induced co-dominant mutation for dwarfness in lentil. Indian Journal of Genetics and Plant Breeding 51: 370-372

Tigist Dejene, (2003). Genetic variability and associations among yield and yield related characters in exotic lentil lines (Lens culinaris Medik.). M.Sc thesis. Alemaya University, Ethiopia.

Vir, O., Gupta, V.P. and Vir, O.P. (2001). Association among yield and yield contributing characters in macrosperma and microsperma derivatives of lentil. Crop Improvement 28(1): 75-80.

Wright, S. (1991). Correlations and causations. Journal of Agricultural Research 20:557-587.

Yadav, J.K., Singh H.L. and Kumar R. (2003). Determining selection components in chickpea (Cicer arietinum L. Wilczek). Plant Archives 3: 125-128. 